\title{
POSSIBILITIES FOR PROVIDING HEALTHY NUTRITION FOR DEVELOPING CHILDREN IN PRIMARY SCHOOLS IN LATVIA
}

\author{
Anita Olšteine ${ }^{1}$, Maira Laterere ${ }^{2}$, Lolita Paegle ${ }^{2}$, Sigita Boča ${ }^{2}$, Dalija Segliṇa ${ }^{1, \#}$, \\ and Imants Skrupskis ${ }^{2}$ \\ ${ }^{1}$ Institute of Horticulture, Latvia University of Agriculture, 1 Graudu Str., Dobele, LV-3701, LATVIA \\ ${ }^{2}$ Faculty of Food Technology, Latvia University of Agriculture, 22 Rīgas Str., Jelgava, LV-3015, LATVIA \\ \# Corresponding author, dalija.seglina@ Ilu.Iv
}

Contributed by Dalija Segliṇa

\begin{abstract}
The resources for optimal growth are biologically valuable substances that ensure life, and their consumption needs to be balanced and moderate with an adequate eating plan. Survey showed that $84 \%$ of respondents chose food products with low nutritional value and high energy value. The general aim of the research was to evaluate the eating habits of primary school pupils and to compare the tendencies in city and regional schools. Catering services are very different schools of Latvia in terms of both mealtimes and prices. Basic criteria were elaborated for estimation of catering quality for children in schools. It was found that $36 \%$ of school children in out-of-school conditions regularly consumed snacks with simple carbohydrates on a daily basis. For better utilisation of food, fresh unprocessed fruits and berries with high mineral and vitamin content have great significance. Pectin found in black currants is used as a natural gelling agent. Structured fruit puree was found to have the most important physical-chemical and sensory parameters. Recommendations to improve healthy eating habits of school children were developed.
\end{abstract}

Key words: pupils, fruits, nutritional value, quality.

\section{INTRODUCTION}

Food is vital to life. It provides the human organism with energy, and it is necessary for physical activity, physiological processes as well as intellectual development. The importance of fruit and vegetable consumption in healthy nutrition was emphasised in the EU Commission's White Paper in relation to nutrition and health issues. The diet of youth has changed significantly and fruit consumption is considerably lower than it used to before. The physiological demand for nutrients already increases in children at the age of 7 till 10, because then the young body rapidly develops (Stang and Story, 2005). Wholesome food is not only the amount of necessary calories consumed, but it also ensures the nutritional value and balance of the consumed food products. Children with healthy nutritional habits have a lower risk of falling ill with such chronic diseases as coronary heart and vascular diseases, cancers, sugar diabetes type 2, etc. (Borah et al., 2015). There is a greater possibility that healthy eating habits will be maintained also at a mature age and passed over to the next generations. Healthy eating habits have a positive effect on teeth and month health, the child's feelings and, the body's nutritional status and body mass.
During recent years, the nutrition policy in Latvia has been forced to pay greater attention to nutrition principles and their planning in schools. Several measures have been taken to improve eating habits of children. In order to provide wholesome nutrition, pupils of grades 1 to 4 receive state-paid lunches with a specific quality criterion, excluding from the menu low-value and unhealthy food products. Since the school year 2010/2011, the EU Programme "School Fruit Scheme" has been introduced in schools for supplying schools with fruits and vegetables.

Dietary fibre is a group of a wide range of complex compounds presented in both soluble and insoluble form, that resist digestion by enzymes present in the human gastrointestinal tract. Studies have shown that dietary fibre components have beneficial physiological effects in humans. The World Health Organisation recommends 30-35 g dietary fibre as the average daily requirement. The desirable proportion of the insoluble and soluble fibre is $3: 1$. The amount of the consumed dietary fibre in Europe is on average 20-25 g per day per person, while in Asia and Africa it is five or even six times higher (150 g) (Shin, 2012).

Cereals are the main source of insoluble fibre such as cellulose, lignin and hemicelluloses, while fruits, berries, and 
vegetables are the primary sources of soluble forms of fibre like pectic substances; however, in lesser quantities cellulose, hemicelluloses and resistant starch are also present (Moreno-Sinchez et al., 2006).

There is a high fibre content in blackcurrants, on average $6.8 \mathrm{~g} \cdot 100 \mathrm{~g}^{-1}$, mostly found in berry skin (Sojka et al., 2009). In comparison with bush bilberries and raspberries, blackcurrants have $40 \%$ higher anti-oxidative activity. Polyphenolic compounds in berries play an important role by their ability to stabilise free radicals. Analysis of anthocyanins in different types of berries showed that blackcurrants are a very promising source of biologically active substances. It has been established that blackcurrants contain 37 times more biologically active substances than red currants (Hegedus et al., 2008). The most prevalent anthocyanins were delphinidin 3-ruthynosid (27-34\%), cyanidin3-ruthynosid (33-38\%), delphinidin 3-glucoside $(8-10 \%)$ and cyanidin3-glucoside (8-10\%) (Rubinskiene et al., 2004).

Apples are the most popular consumed fruits worldwide. The content of fibre in apples is between 2-3 g. $100 \mathrm{~g}^{-1}$, including both soluble and insoluble forms. Soluble fibre, such as pectin, represents $2 \%$ of the total amount of fibre (Aprikian et al., 2003). It has been reported that this fraction probably contributes to the effects of apples on lipid metabolism (Cara et al., 1993). The total amount of pectin in the form of protopectin, pectin and pectic acid in apples was estimated to be $0.3-1.8 \%$ (Boca, 2013).

To ensure balanced meals, diverse food products should be included in the pupil's diet, since each of them contains particularly significant and useful compounds that regulate vital body processes. Since metabolic processes result in transformation of organic substances, the availability of the required substrates/products should be ensured. An insufficient amount of a nutrients can result in physiological and emotional disorders.

A continuously biased child's nutrition with little assortment of foodstuffs does not satisfy the demand for balanced food. A child's disturbed condition can be especially reflected by the relationship with the food he/she consumes. For example, a child's enhanced desire for sweets or excessive use of energy sources may be based on an emotional deficiency. Some children often do not want or are not inclined to try some other food products not used before or they do not eat a very wide range of products. A child can be too addicted to eating food of habitual texture and taste (Dunlap, 2004). The principles of using healthy food are based on nutrients consumed during meals, though not only for energy sources, but also frequency, regularity of their consumption, optimal nutrient maintenance and correct distribution of servings per day make an optimal impact of food on the functions of the child's body. Breakfast is considered to be one of the most important meals for a primary school pupil during the day. It has been proved that breakfast positively influences primary school pupils' cognitive processes, in particular, memory, hearing, and attention
(Mahoney et al., 2005). Breakfast is of great significance in children's nutrition, because after a night's sleep, the energy resources accumulated during the previous day are exhausted in the child's body (Kozule and Straume, 2007). An omitted breakfast can very often cause children to feel great hunger and problems waiting for the meal at noon. Due to hunger they are not capable of understanding the subject taught and they feel tired (Borah et al., 2015). In order to avoid constant feeling of hunger, it would be optimal to introduce lunch in the school's catering system at least for pupils from grades 1 and 2 . It is not envisaged to increase the total energy ration during the day by additional meals. If the planned energy amount is consumed in 2 or 3 meals, the usage of food in the body becomes worse. For example, only $75 \%$ of nutrition proteins are used, and if there are 3-4 meals, the feeling of hunger is not observed and proteins are used up to $85 \%$ (Borah et al., 2015). The resources for optimal growth consist of biologically valuable substances of vital necessity, and their balanced, moderate consumption in the diet. Survey has shown that $84 \%$ pupils basically choose products with low biological value and high energy value. High content of biologically active substances in the diet can be ensured by blackcurrant pomace in the composition of different food products as functional food ingredients (Helbiga et al., 2008; Sojka et al., 2009). Particularly healthy and recommended food are local and seasonal fresh and processed fruits such as apples.

The general aim of the study was to evaluate the eating habits of primary school pupils and to compare the tendencies in the city and regional schools. Within the framework of the current research, a related objective was to evaluate the nutritional value and chemical composition of blackcurrant and apple products.

\section{MATERIALS AND METHODS}

Conditions of the interview. During the study, 146 children and their parents were interviewed, with 292 respondents. Pupils from 7 to 10 years from different primary and elementary schools as well as their parents were interviewed on healthy lifestyle. One city elementary school (Andrejs Pumpurs Rīga Elementary School No. 11) and three rural primary schools (Ramata, Mazsalaca, and Pārgauja primary schools) were involved in the current research. From the total amount of respondents, $20 \%$ or 22 of pupils were seven years old, $35 \%$ or 51 were 8 years old, $30 \%$ or 44 were 9 years old, and $20 \%$ or 22 pupils were 10 years old. The body mass index, weight, and height of the children were measured. The eating habits of primary school pupils were determined by using questionnaires. In order to exclude any bias, not only the children's but also the parents' (average age 37.2 years) eating habits were clarified and the results were evaluated. Using qualitative evaluation, school menus provided by cafeterias were evaluated in terms of product availability and diversity. Furthermore, based on the available information, caloric value of the offered meals was calculated. The study was conducted according to a confirmation by the Ethics Committee of the 
Institute of Experimental and Clinical Medicine, University of Latvia.

Evaluation of nutritional value of blackcurrant and apple products. Apple cultivars 'Baltais Dzidrais', 'Antonovka', and 'Zarja Alatau' in different stages of maturity were harvested in the orchard of the Institute of Horticulture, Latvia University of Agriculture. In order to evaluate apple physical-chemical characteristics, the apples were blended unpeeled and grated through a sieve to obtain a homogenous mass. The obtained products were kept in the refrigerator at $-18 \pm 2{ }^{\circ} \mathrm{C}$ until analysis. Concentrations of sugars, total pectin, $\mathrm{pH}$, soluble solid, and total acids were determined and sensory evaluation was performed in fresh and frozen apple puree according to the methods provided by S. Boca (2013).

The three most common blackcurrant varieties ('Ojebyn', 'Titania', and 'Vernisazh') grown in commercial orchards of Latvia were used in the study. Juice from blackcurrant berries was obtained by two methods: (1) squeezing method - frozen berries were defrosted at room temperature $(+18$ $\pm 2{ }^{\circ} \mathrm{C}$ ) for 24 hours with juice and pomace obtained by a screw type press "CONDO LINE", and (2) heating method - frozen berries were put into the vapour kettle to separate evaporated juice and pomace from berries. The extracted pomace was dried at $+50{ }^{\circ} \mathrm{C}$ temperature, milled with a "FRITSCH" mill using a $0.5 \mathrm{~mm}$ coarse sieve, pre-packed by covering with a foil material and stored at $+18 \pm 2{ }^{\circ} \mathrm{C}$ temperature. Concentrations of fibre, phenolics, anthocyanins, vitamin $\mathrm{C}$, soluble solids, total acids, as well microelements were determined by methods described by A. Olsteine (2012).

\section{RESULTS}

Evaluation of eating habits in schools. When comparing city and rural schools in terms of catering service and assortment available, differences in meals were observed.

There were 200 pupils in city primary school grades at Andrejs Pumpurs Elementary School No. 11 in Rìga. The school used catering services. In the Pārgauja City Primary School in Valmiera, where 250 pupils of grades 1 to 4 were enrolled, the organisation of lunch was much more complicated than in rural regional schools. Lunch breaks in both schools were organised two times for 30 minutes. According to the school healthcare person's information, children had free access to the products offered by the programme "Milk for School", which favours children's healthy habit of using milk daily. In both schools there was a cafeteria available where lunch was provided for additional cost.

In the Mazsalaca Rural Primary School, analysis of the weekly lunch menu showed that every weekday pupils were provided with a full menu including soup, a main course, and a sweet snack. Cooking methods are diverse. Mainly boiled and fried dishes were offered to pupils. The average energy value rate of the daily complex that the lunch offered was $748.02 \mathrm{kcal}(736-768 \mathrm{kcal})$ per serving, which is acceptable. In general, the weekly menu provided nutrient (proteins: fats: carbohydrates in a ratio $1: 1.1: 3.6$, which almost corresponds to the recommended ratio of $1: 1: 4$. For the pupils of Mazsalaca Primary School the lunch menu was differentiated also by the choice of products. Products of different groups were included — vegetables, fruits, cereals, meat, milk, etc. Since there was no cafeteria in the school and children did not have a possibility to obtain snacks if they felt hungry between meals, an afternoon snack was provided before leaving for home at about 2 p.m. It was possible to mitigate the children's hunger with a glass of milk. In Ramata Rural Primary School it was observed that pupils received also some additional berries or juice at mealtime, which added to the diversity of food.

Within the framework of the research it was estimated that the average number of pupils in city schools is approximately 450-500. Lunch breaks between the lessons are organised in several stages. Lunch organisation in rural regions is different from that of a city. In three of four primary educational establishments there were cafeterias available for children, where it was possible to purchase different snacks to mitigate sudden hunger. The schools involved in the research had joined the programme "School Fruit Scheme" funded by the European Commission, which provided a healthy snack supply for the primary school pupils during the day. Differences in the meals were observed in the menus, which did not always provide a balanced diet.

In order to evaluate the parents' competence in nutrition issues, a question for parents was included in the questionnaire: in the parents' opinion, whether the child is provided with healthy and balanced food on a daily basis. About $80 \%$ of the surveyed parents stated that the child was provided with healthy food, while $20 \%$ declared the opposite. The study showed that a child's eating culture is inherited from his/her parents, and that the parents' understanding and practising of a daily healthy eating is reflected in the child's choice of food. The parents' responses in the questionnaire were assessed by the types of dishes and snacks the pupils chose.

A direct question regarding a healthy snack was included in the children's questionnaire, where children had to mark the healthiest one from the three types of snacks of which only one of those included in the list was healthier than the other two. The obtained results indicated that the children's point of view on healthy food differed in different periods of their age (Fig. 1). In the group of 7 -year-olds, $48 \%$ of the chil-

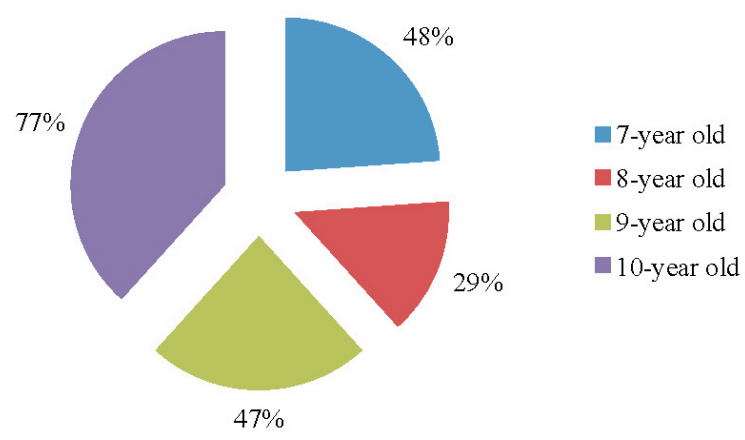

Fig. 1. Children's understanding about healthy snacks. 


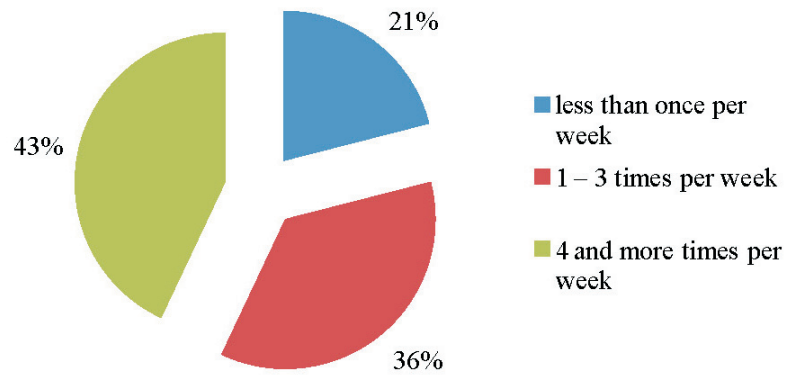

Fig. 2. Regularity of fruit and vegetable consumption.

dren marked the healthiest snack, in 8-year olds $-29 \%$, in the 9 -year-old group - $47 \%$, whereas $77 \%$ of the oldest respondents indicated the healthy type of snacks. This difference among 9 and 10-year-old primary school pupils can be explained by better understanding of older children about healthy products, which do not harm health. The knowledge reflected in the responses given by 9 -year-olds about healthy snacks continue to improve until the age of 10 . Most of the children's opinions were in accord with those of their parents. However, the obtained results do not reflect the real situation of children's and parents' knowledge about healthy and balanced food. Fruits and vegetables formed the basis of healthy food in consumption by almost half of the inquired children (Fig. 2).

Evaluation of the nutritional value of blackcurrant and apple products. Blackcurrant pomace, depending on the juice extraction technology, contains a large amount of fibre (37.5-43.5 \% $100 \mathrm{~g}^{-1}$ ), including $7.4-13.7 \%$ of wood-fibre (Olsteine, 2012). In a study of the effect of blackcurrant variety and juice extraction technology on the chemical composition of pomace (Olsteine, 2012), it was observed that dried, ground pomace contained a significant amount of antioxidants, including polyphenols (1.8-2.0 g $\left.100 \mathrm{~g}^{-1}\right)$, anthocyanins $\left(0.1-0.8 \mathrm{~g} \cdot 100 \mathrm{~g}^{-1}\right)$, and vitamin $\mathrm{C}$ (25.1-80.2 mg.100 $\mathrm{g}^{-1}$ ). Blackcurrant pomace is a rich source of microelements: $2.5-7.7 \mathrm{mg} \cdot 100 \mathrm{~g}^{-1}$ iron, 965-1296 mg.100 g potassium, and 6.5-10.6 mg.100 g $\mathrm{g}^{-1}$ magnesium (Table 1).

Table 1

PHYSICAL AND CHEMICAL COMPOSITION OF BLACK CURRANT POMACE POWDER

\begin{tabular}{|c|c|c|}
\hline \multirow[b]{2}{*}{ Indices } & \multicolumn{2}{|c|}{ Pomace } \\
\hline & $\begin{array}{c}\text { squeezing } \\
\text { method }\end{array}$ & $\begin{array}{l}\text { heating } \\
\text { method }\end{array}$ \\
\hline Total fibre, $\%$ & $37.5-42.5$ & $43.2-43.5$ \\
\hline Crude fibre, $\%$ & $7.4-12.6$ & $10.5-13.7$ \\
\hline Total phenolic compounds, $\mathrm{g} \cdot 100 \mathrm{~g}^{-1}$ & $1.84-3.22$ & $1.18-2.02$ \\
\hline Total anthocyanin compounds, $\mathrm{g} \cdot 100 \mathrm{~g}^{-1}$ & $0.65-0.83$ & $0.13-0.25$ \\
\hline Vitamin $\mathrm{C}, \mathrm{mg} \cdot 100 \mathrm{~g}^{-1}$ & $53.1-80.6$ & $25.1-35.6$ \\
\hline Iron, $\mathrm{mg} \cdot 100 \mathrm{~g}^{-1}$ & $3.5-7.7$ & $2.5-5.9$ \\
\hline Potassium, mg. $100 \mathrm{~g}^{-1}$ & $1080-1280$ & $965-1296$ \\
\hline Magnesium, mg.100g ${ }^{-1}$ & $8.0-.8$ & $6.5-10.6$ \\
\hline Soluble solids, ŗBrix & $54.1-57.7$ & $51.1-57.7$ \\
\hline Total acid content, $\%$ & $12.6-16.5$ & $12.3-14.4$ \\
\hline
\end{tabular}

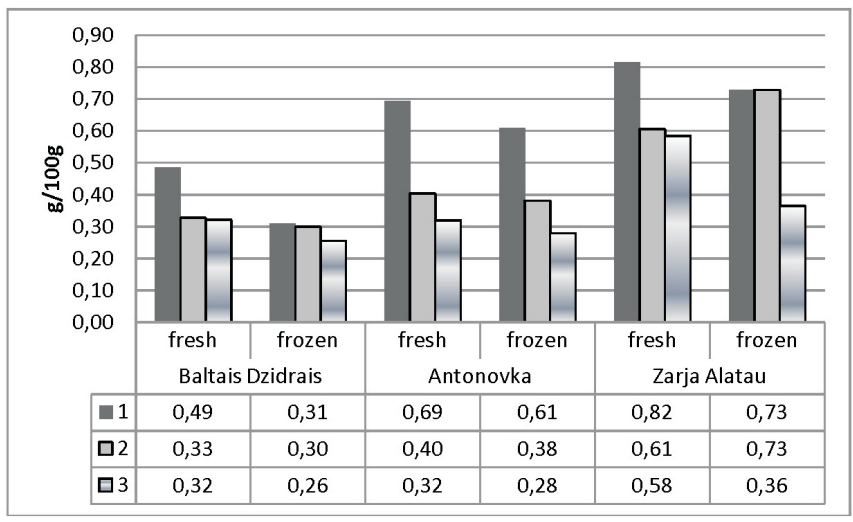

Fig. 3. Pectin quantity in fresh and frozen apple puree.

The content of pectin in apple puree prepared from the studied cultivars depended on the cultivar and was closely related to the ripeness stage of the apple, which is characterised by the concentration of soluble solids and $\mathrm{pH}$ in the apples. Decrease of pectin concentration occurs as a result of pasteurisation and freezing. The pectin concentration during three months of storage dicreased less in the cultivar 'Zarja Alatau' (29.27\%) and during freezing in the cultivar 'Baltais Dzidrais' (16.13\%) (Fig. 3). A close correlation between the concentration of soluble solids and pectin in fresh apple purees was observed $(r=0.902)$. In fresh apple puree, the concentration of fructose was the highest (6.3 to 7.0 g. $\left.100^{-1}\right)$. Its concentration increased on average by $11.5 \%$ during pasteurisation, and by $6.6 \%$ during freezing. The positive sensory evaluation of apple puree with low amounts of sugar allowed to include fruit desserts in school menus as a lower calorie dessert. Fresh apple purees of autumn-winter cultivars and frozen apple puree can enrich the pupils' diet with valuable nutrients for the body throughout the year (Boca, 2013).

\section{DISCUSSION}

It was observed that a pupil typically consumes a meat meal together with starchy carbohydrates such as potatoes, or cereal products. Imbalanced combination of alkaline and acid medium of such products can result in some digestive problems (Dunlap, 2004). The gastrointestinal tract $\mathrm{pH}$ is highly acidic (ranging from 1.0 to 2.5 ). Consumption of food products, whose $\mathrm{pH}$ level is more acidic than alkaline (rye bread, sweetened drinks) increases the acidic medium in the human gastrointestinal tract. Such products were widely distributed and readily available to the pupils in the surveyed schools. With the aim to improve such a situation, acidic food products should be combined with the alkaline ones. For example, dishes presented in school menus should include both meat and fresh or stewed vegetables. By following such a combination of acidic and alkaline food products, it is possible to provide a neutral gastric medium of $\mathrm{pH} 7$. When developing school menus the ratio of acidic and alkaline products should be 1:2. It is well established that during thermal processing of foods, not only the amount of pathogenic microorganisms is reduced, but also the nutritional 
value of the product. Therefore, stewing and blanching should be practiced more frequently due to the mild thermal process that ensures not only the suppression of microorganisms, but also the preservation of biologically active compounds. It is essential to be aware that the consumer of the school catering system services is a child. It is important to take into consideration the child's wishes regarding the food, and at the same time the child's eating habits have to be formed. In preparing the school menu, it is important to consider the child's wishes as much as possible, and taking them as a framework, a healthy eating plan has to be created. Educational establishments involved in the study supplied children with meals twice a day; the prepared lunch and snack provided energy consumption during the day while being at school.

Although lunch for the children is paid by the state, children's parents have to pay additionally for the snack. Mainly boiled and fried dishes are offered to pupils, although the most optimum cooking methods that are recommended are stewing or blanching, because by using these methods losses of valuable nutritional substances are lower than when frying at a high temperature. Although frying and boiling are the most beneficial methods for the economy of time resources, probably, also at home children are offered cooked meals that used the same methods. It would be essential for parents to take into consideration the choice of products and methods of cooking offered in the school menus. Otherwise there is possibility that a child both, at home and at school, consumes the same type of food. Often there is an opinion that pupils are not satisfied with the offered food catering at schools, because it does not correspond to the usual food cooked at home. For example, a child who at home is provided with food from raw foodstuffs which are quickly cooked convenience foods, then at the school dinner table, the child can refuse to eat soups, main courses and desserts, because for this child it is unacceptable to eat such dishes. Organoleptic properties of foods are different and the cooking technology can differ between school and home-made food. The argument has been proved repeatedly that parents have a great responsibility for a child's healthy development by creating the environment of healthy and balanced food. It is possible to optimise the regulation possibilities of heat processes for different ripeness stages of apples. It has been established that the ripeness stage influences the pectin quantity in fruits, but the pectin quantity changes in frozen fruits is usually ignored.

Although children's dissatisfaction with food cooked at school was not observed in the study, more attention should be paid to the atmosphere in the lunch room during the meal-time. Children should feel comfortable in an informal environment; they should have the possibility to choose the food they prefer. Probably at a younger age in primary school the children are supervised and after school activities spend more time together with their parents or with some other adults. Therefore, there are definite food product groups used in nutrition and their healthy nutrition is considered by parents. During the next age period, children probably become more independent and the primary school pupils are more in charge of themselves in terms of individual food provision. When parents give their children pocket money, they go to the shopping places and choose the food they prefer to eat. Due to the overwhelming amount of food products and lack of knowledge, the children are still not able to evaluate their state of healthiness. The primary school programme on healthy lifestyle, including information about healthy food, has to be acquired by primary school pupils in grade 3, approximately at the age of 9 years (Dixey et al., 2006). One of the aspects is to use healthy and qualitative products in the diet, but if other principles of balanced food like sufficiency and balance are not followed, then harm to health can be caused.

As a result of the juice extraction process from fruit and berries, pomace is formed (consisting of seeds, peel, and stem), which, like juice, contains biologically active substances for the human body, including natural antioxidants like polyphenols, vitamin $\mathrm{C}$, mineral substances and other compounds (Tsybikova et al., 2003; Novruzov, 2005). Pomace from different berries is widely used in the world, for example, to extract oil, to improve nutritional value of bread, pastry and different cereal products, and in beverage production (Sojka et al., 2009). Pastry and bread products with increased nutritional value, which are developed by adding the pomace from different fruits and berries including blackcurrants and apples to products, are suitable for a pupils' menu (Anonymous, 2001; Korus et al., 2011). In Korea, big amounts of cereal and vegetable products are used to prepare pupils' meals, as a result of which the content of insoluble and soluble fibre is high: cellulose $109.7 \pm$ $11.7 \%$ (range $90 \sim 150 \%$ ) and pectin $77.8 \pm 10.8 \%$ (range 64.7 96.7\%), respectively (Shin, 2012).

\section{REFERENCES}

Anonymous (2001). Advanced Dietary Fibre Technology. Clearyand, B. V., Prosky, L. (eds.). Wiley-Blackwell Science, 572 pp.

Aprikian, O., Duclos, V., Guyot, S., Besson, C., Manach, C., Bernalier, A., Morand, C., Remesy, C., Demigne, C. (2003). Apple pectin and a polyphenol-rich apple concentrate are more effective together than separately on cecal fermentations and plasma lipids in rats. J. Nutr., 133 (6), 1860-1865.

Boca, S. (2013). Factors influencing fruit dessert quality. Doctoral Thesis. Latvia University of Agriculture, Jelgava, Latvia.

Borah, P. K., Devi, U., Biswas, D., Kalita, H. C., Sharma, M., Mahanta, J. (2015). Distribution of blood pressure \& correlates of hypertension in schoolchildren aged 5-14 years from North-east India. Indian J. Med. Res., 142 (3), 293-300.

Cara, L., Dubois, M., Armand, N., Mekki, M., Senft, M., Portugal, H., Lairon, D. (1993). Pectins are the components responsible for the hypercholesterolemic effect of apple fiber. Nutrition, 12, 66-77.

Dixey, R., Heindl, I. Loureiro, I., Pérez-Rodrigo, C., Snel, J., Warnking, P. (2006). Healthy eating for young people in Europe. A school-based nutrition education guide. Available from: http://www.euro.who.int/_data/assets/pdf_file/0005/119921/E69846.pdf (accessed 4 October 2016).

Dunlap, L. L. (2004). What All Children Need. Theory and Application. Second edition. University Press of America, Oxford; NewYork. 266 pp.

Hegedus, A., Balogh, E., Engel, R., Sipos, Z. B., Papp, J., Blazovics, A., Stefanovits-Banyai, E. (2008) Comparative nutrient element and antioxi- 
dant characterization of berry fruit species and cultivars grown in Hungary. Horticult. Sci., 43 (6), 1711-1715.

Helbiga, D., Bohmb, V., Wagnera, A., Schuberta, R., Jahreisa, G. (2008). Berry seed press residues and their valuable ingredients with special regard to black currant seed press residues. Food Chem., 111, 1043-1049.

Korus, J., Juszczak, L., Ziobro, R., Witczak, M., Grzelak, K., Sojka, M. (2011). Defatted strawberry and blackcurrant seeds as functional ingredients of gluten free bread. J. Texture Stud., 41 (1), 29-39.

Kozule, V., Straume, I. (2007). Sabalansētu ēdienkaršu sastādīšana 1-4. klašu skolēniem [Balanced compilation of menus for 1-4 grade pupils]. Latvijas Republikas Veselības Ministrija, Rīga. 80 lpp. (in Latvian).

Mahoney, C. R., Taylor, A.H., Kanarek, R. B., Samuel, P. (2005). Effect of breakfast composition on cognitive processes in elementary schoolchildren. Physiol. Behav., 85 (5), 635-645.

Moreno-Sánchez, C., Teresa, P. S., DeAncos, B., Cano, P. M. Nutrition values of fruits. (2006). In: Handbook of Fruits and Fruit Processing. Hui, Y. H. (ed.). Blackwell Publishing, pp. 29-44.

Novruzov, E. N. (2005). Carotenoids and stearines of seabuckthorn (Hippophaerhamnoides L.). In: Seabuckthorn (Hippophae L.): A Multipurpose Wonder Plant. Singh, V. (Ed.). Daya Publishing House, India, New Delhi, pp. 177-196.
Olsteine, A. (2012). Analysis of blackcurrant qualitative indices. Masters thesis. Latvia University of Agriculture, Jelgava, Latvia.

Rubinskiene, M., Viskelis, P, Jasutiene, I., Dambrauskiene, E. (2004). Anthocyanins and their variation in black currant berries and products. Lithuanian Agricultural Library.

Shin, D. (2012). Analysis of dietary insoluble and soluble fiber contents in school meal. Nutr. Res. Pract., 6 (1), 28-34.

Sojka, M., Guyot, S., Kolodziejczyk, K., Krol, B., Baron, A. (2009). Composition and properties of purified phenolics preparations obtained from an extract of industrial blackcurrant (Ribesnigrum L.) pomace. J. Hortic. Sci. Biotechnol., ISAFRUIT Special Issue, pp. 100-106.

Stang J., Story M. (eds.) (2005). Guidelines for Adolescent Nutrition Services. University of Minnesota, Minneapolis, MN, pp. 21-34.

Tsybikova, G. T. S., Tsybikova, D. T. S., Dorzhiyeva, A. A. (2003). Seabuckthorn (Hippophaerhamnoides L.) fruit residue flour for production of quality food products. In: Seabuckthorn (HippophaeL.): A Multipurpose Wonder Plant. Singh, V. (ed.). Indus Publishing Company, India, New Delhi, pp. 479-482.

Vidya, R., Kumar, P. (2014). Effect of breakfast skipping on nutritional status and school performance of 10-16 years old children. Health. Popul. Perspect. Issues., 37 (3-4), 98-117.

Received 7 October 2016

Accepted in the final form 18 October 2017

\section{AUGOŠAM ORGANISMAM NEPIECIEŠAMĀS BIOLOG̣ISKĀS VĒRTĪBAS NODROŠINĀŠANAS IESPĒJAS VESELĪGA UZTURA PIEDĀVĀJUMAM PAMATSKOLĀS}

Būtiski apzināties, ka skolu ēdināšanas pakalpojumu saṇēmējs ir bērns. Tā vēlmes attiecībā uz êdienu ir svarīgi ievērot, taču vienlaicīgi arī jāveido skolēnu ēšanas paradumi. Optimālas augšanas resurss ir bioloğiski vērtīgas, dzīvībai nepieciešamās vielas, to sabalansēta, mērena uzṇemšana un ēšanas režīms. Skolēniem ir tendence izvēlēties bioloğiski mazvērtīgus êdienus, tā radot apdraudējumu savai veselībai un organisma attīstībai. Ēdienkartē regulāri jāiekḷauj aug̣̣i un ogas, īpaši ieteicami ir sezonai atbilstoši svaigi aug̣̣i. Šie produkti jauno organismu nodrošina ar vitamīniem, minerālvielām, šḳiedrvielām. Pētījuma mērḳis ir, skolēniem aktīvi iesaistoties, veidot veselīgus ēdināšanas un uztura lietošanas paradumus. Organisma imunitātes veicināšanai un fizioloğisko funkciju uzlabošanai uzturā tiek uzņemtas bioloğiski aktīvās vielas. Šādas vielas nav jāuzṇem atseviški, jo tās jau ietilpst produktu sastāvā, kas ikdienā tiek uzṇemtas ar uzturu. Bērna uzturā būtiski ir maksimāli šīs vielas saglabāt un panākt optimālu to uzsūkšanos organismā, tāpēc svarīgi izvēlēties pareizu ēdiena pagatavošanas veidu. Katram vitamīnam un minerālvielai organismā ir noteikta bioloǵiska vērtība. Uzņemot attiecīgu pārtikas produktu vai kombinējot tos, tiek nodrošināta skolēnam nepieciešamā dienas deva. Bāziskas vides pārtikas produktu ieklaušana uzturā atstāj pozitīvu efektu uz kaulu veselību, kas ir būtiski organismam augšanas periodā. Tāpēc veikti padziḷināti pētījumi par škiiedrvielu un pektīnu saturošiem produktiem uz upeņu un ābolu izejvielu bāzes, kas reizē arī ḷauj paplašināt ēdienu sortimentu un pagarināt izmantošanas laiku sezonas produktiem. Progresīvas konservēšanas metodes — saldēšanas pielietošana jaunu produktu izstrādei var palīdzēt risināt šo problēmu. 